\title{
Effect of Human Capital Management on Firm Performance via Balanced Scorecard
}

\author{
Khadra DAHOU ${ }^{1}$ \\ Ishaq HACINI ${ }^{2}$
}

\begin{abstract}
Nowadays, there is an increasing reliance on intangible assets as important determinants of firm value. Research was focused on the influence of human capital as an intangible asset on the organizations' performance. This paper makes insights by exploring the concept of human capital management HCM and the impact of the balanced scorecard BSC on it and the effect of both on firm performance. The model was developed to include HCM indicators, deducted from resource-based and motivation theories, "competence" and "motivation \& commitment". The model also includes the four areas of the BSC: learning \& growth, internal business, customer and financial performance; in addition to firm performance as research dependent variable. Data was collected from the 4 telecommunication organizations in Jordan, using 65 questionnaires. The hypotheses were tested using Amos analysis to determine the impact of using Balanced Scorecard BSC on Human Capital Management $H C M$, and the impact of both variables on Firm performance. The results revealed that the BSC has significant impact of effective human capital management; and both have positive effect on firm performance. They also revealed the primordial inter-functional strategic role of BSC and how important is the investment on commitment \& motivation and competencies that would certainly lead to increase firm performance.
\end{abstract}

KEYWORDS: Human Capital Management, Balanced Scorecard, Firm Performance.

JEL CLASSIFICATION: L25, M12, $M 41$.

\section{INTRODUCTION}

To compete and survive, the organizations have to catch opportunities and invest in its resources especially by relying on intangible assets to increase performance. The human resources represent the most important asset and the source of the organizations' competitive advantage. Resources based view of the firm provides a frame work to help understanding the potential sources of competitive advantage that could be generated through investments in human capital, in the extent they are valuable, rare, inimitable and difficult to substitute.

The financial accounting systems report business results, tracking tangible assets, but give little insight into the measurement and management of intangibles (Huselid \& Barnes, 2003). Accounting research in the 1970s focused on establishing techniques to measure the cost and value of the work force. Moreover, lack of consensus measure impeded the development of related issues to human capital accounting.

The balanced scorecard is a methodology helping managers focusing on the drivers of the primordial indicators of the firm performance. It provides little insight into the management

\footnotetext{
${ }^{1}$ Associate Professor at Faculty of Economics \& Management, Mascara University. Algeria, dahou.khadra@yahoo.fr

${ }^{2}$ Associate Professor at Faculty of Economics \& Management, Mascara University. Algeria, ishaq_zida@yahoo.fr
} 
of intangibles. By focusing on intangibles, especially human capital, special functional scorecards were designed as measurement systems, explaining the way human capital improves their performance and achieves the organizations' competitive advantage (Huselid \& Barnes, 2003).

Through this paper, the researchers want to make insights on what means the concept Human Capital Management, and making linkage with the Balanced Scorecard, and the effect of this relationship on the firm performance. The researchers aim is to study: "The Effect of Human Capital Management on Firm Performance Via Balanced Scorecard”

The study seeks to fulfill the following objectives:

- Review of the literature on the concepts of Human Capital Management and Balanced ScoreCard

- Identify indicators that measure and drive human capital management leading to enhance firm performance

- Approve the reality of the importance and the central role of HCM in improving firms' performance through examining and analyzing this reality in Jordanian telecommunication organizations.

- Understand to what extent the use of Balanced Scorecard can lead to firm performance improvement.

- Develop relationship between Human Capital Management, Balanced Scorecard and Firm Performance

\section{THEORETICAL FRAMEWORK}

Recently, intangible assets are recognized as the organizations' source of competitive edge. The impact of the human resources on firms' performance has taken attention in research, where numerous studies have established the positive linkage between high performance HR practices and superior firm performance. The human resources form the firms' culture, create differences, and embrace knowledge management processes, to promote the firms' performance. The human resources are the ultimate drivers of success in any organization.

\subsection{Human Capital Management}

\subsubsection{Approaches to Human Capital Management}

Two approaches have taken the study of human capital and identifying its potential, giving reference to its role from different perspectives: resources-based view and institutional theory. An approach that combines the resources-based view with institutional theory is capable of explaining and supporting relationship between HCM and firm performance.

\subsubsection{Resource Based theory}

The resource-based theory explained that the organization's competitiveness and profit is a function of its resources. Those resources represent: "all assets, capabilities, competencies, organizational processes, firm attributes, information, and knowledge that are controlled by a firm" (Barney, 2002, p.155). Resource-based theory identifies the valuable, rare, difficult to copy and non-substitutable resources, achieving a competitive edge and leading the organizations ahead the competition.

The RBV include resource heterogeneity: possessing rare and non-substitutable resources making it different; and resource immobility, defined by Barney (2002) as these too-costly-tocopy resources, hard to move across organizations (Hsu, 2006). Human capital is one of the 
most important resources to a firm performance. More recently, this perspective has been extended to consider dynamic capabilities, a firm's unique "ability to achieve new and innovative forms of competitive advantage given path dependencies and market positions"(Teece, Pisano \& Shuen, 1997, p.516).

\subsubsection{Institutional theory}

Based on Resource Based theory's deficiencies, the Institutional theory suggests taking into account the social factors like norms, values when designing the organizations' strategy.

The institutional view suggests that the motives for human behavior extend beyond economic justification and social obligation (Oliver, 1997, p.699), and that institutionalized activities are the result of interrelated processes at the individual, organizational, and interorganizational levels of analysis (Molina \& Ortega, 2002).

\subsubsection{Human Capital Management}

The human capital importance increases incredibly in today's business. Human capital management (HCM) has been described as 'a strategic approach to people management that focuses on the issues that are critical to an organization's success' and 'the possession of knowledge, applied experience, organizational technology, customer relationships and professional skills that provides a company with a competitive edge in the market'(Hartley \& Robey, 2005).

Used for the first time by Nobel Laureate, Theodore W. Schultz, in the 1961 American Economic Review Article, 'Investment in HC'; Human capital is a constituent of the 'intellectual capital: 'Recent estimates suggest that 50 to 90 per cent of the value created by a firm comes, not from management of traditional physical assets, but from the management of intellectual capital' (ICAEW, 1999, p. 2 cited in Hartley \& Robey, 2005, p. X).

Human Capital Management (HCM) is primordial to increase and promote the firms' competitiveness via higher performance by investing in their employees: recruiting the best ones, developing their competencies and retaining them within the organizations. HC is "the knowledge, skills, competencies and other attributes embodied in individuals or groups of individuals acquired during their life and used to produce goods, services or ideas in market circumstances" (Westphalen, 1999, p.4).

Human capital management is seen as acknowledging, anticipating, and acting on the human impacts of those actions. Human capital management provides a systems approach to enhance the organizations and employees' performance (Kucharpíková, Tokarbíková \& Blašková, 2015), by integrating initiatives that impact their performance, including restructuring, business process improvement, and new IT systems introductions, as well as more traditional HR programs, such as recruiting, retention, and performance management.

Human capital is generated when an individual or a firm decides to invest resources in the development of people who work in the business. Similar to other investment choices, human capital investment is targeted to higher returns as long as the individual or the firm is rational. In today's technology-dependent, global economy, knowledge and competence of employees become the most important sources of firms' competitive advantages, and this is partially the result of the move from a manufacturing to a service economy.

Two ideas are in the core of human capital: 
1. People are assets whose value can be enhanced through investment. Maximizing indiciduals value via investment and development will lead to improve the organization performance and thus the interests of the clients and stakeholders.

2. An organization's human capital policies must be aligned to support the organization's "shared vision": the organizations' general strategic direction via defining the vision, the mission, the strategies, the goals and objectives (Haslinda, 2009).

As such, it is important for organizations to measure and report on HC management if they want to control, monitor and better invest in their 'most valuable asset'. This has become even more imperative with the growing body of evidence that effective $\mathrm{HC}$ management is directly correlated to performance, competitiveness and ultimately, shareholder value. So, "achieving the competitive edge for individuals, enterprises and societies alike is thus increasingly becoming synonymous with the notion of human capital. This is partly justified by the growing importance of intangible assets in enterprises, of which human capital constitutes a major element and by the emphasis from both public and private bodies on human capital as a savior of competitiveness, reduction of unemployment and expansion of economic wealth "(Westphalen, 1999, p.5).

\subsubsection{Human Capital drivers}

Four specific human capital drivers were identified which can have a substantial effect on firm performance, namely: recruiting excellence, collegial and flexible workplace, communications integrity and clear rewards and accountability. Also commitment and competence were added as two dimensions driving human capital.

Drivers, such as recruiting (including training) and rewards, are seen as long term investment included in human capital investment that researchers have tried to involve in accounting books. "Recruiting excellence allows the firm to acquire employees who either already possess the general human capital necessary to do the jobs required by the business plan, or can be trained in these skills" (p. 231).

Establishment of a collegial and flexible workplace encourages employees working well together. It is about creating appropriate, stable and flexible work arrangement and conditions. Then, promoting communications integrity involves sharing information in a trust environment on employees, allows informal relations; and provides a superior customer service. There needs to be an effective performance management system with clear and fair rewards. (Hsu, 2006; Nyce \& Schieber, 2005; Molina \& Ortega, 2002) Ulrich (1998) defined human capital in term of two components:

1. "competence" that must be aligned with business strategy and generated with many mechanisms;

2. "commitment" referring to the feelings of employees towards each other and towards their organizations (Hsu, 2006).

Table 1. Level and dimensions of human capital

\begin{tabular}{|c|l|l|l|l|}
\hline $\begin{array}{c}\text { Level/ } \\
\text { Dimension }\end{array}$ & \multicolumn{1}{|c|}{ Politics } & \multicolumn{1}{c|}{ Economy } & \multicolumn{1}{c|}{ Sociology } & \multicolumn{1}{c|}{ Psychology } \\
\hline Individual & Increase skills level & Increase earnings & Increase equality & Increase self-esteem \\
\hline Enterprise & $\begin{array}{l}\text { Comply with } \\
\text { surrounding society }\end{array}$ & $\begin{array}{l}\text { Increase } \\
\text { competitiveness }\end{array}$ & $\begin{array}{l}\text { Improve the } \\
\text { enterprise image }\end{array}$ & $\begin{array}{l}\text { Improve work } \\
\text { environment }\end{array}$ \\
\hline Government & $\begin{array}{l}\text { Complement labour } \\
\text { market and } \\
\text { employment } \\
\text { policies }\end{array}$ & $\begin{array}{l}\text { Share the costs related } \\
\text { to education and } \\
\text { training }\end{array}$ & $\begin{array}{l}\text { Implement the } \\
\text { lifelong learning } \\
\text { concept }\end{array}$ & $\begin{array}{l}\text { The notion of a } \\
\text { dynamic government/ } \\
\text { society }\end{array}$ \\
\hline
\end{tabular}

Source: apdated from Westphalen, 1999, p5. 
In this research, researchers have adopted the two factors of competence and motivation \& commitment as drivers of human Capital Management. Because of its increasing prominence, irrespective of its economic origin at enterprise level, human capital is now subject to various levels and dimensions. Table 1 illustrates different levels and dimensions including HC. Dimensions are more interrelated to human capital, especially when reporting on it.

\subsection{Reporting and measurement of on human capital}

\subsubsection{Measuring the Human Capital}

In measuring the human capital, two different methods are identified:

- The "non-economic measurement method" used to measure the stock of human capital.

- The "economic measurement method" used to measure the costs related to acquire, maintain and develop the stock of capital (Westphalen, 1999).

Reporting on human capital faces the lack of a reliable measurement tool.

\subsubsection{Reporting on human capital}

When measuring intangibles, firms are trying to develop their own internal or managerial accounting measurement systems (Huselid \& Barnes, 2003). Over time researchers have proposed different approaches, giving the objective of measuring human capital management, and reporting it for more effective information and better management.

Many approaches were developed to measure and report human capital. Between these applied methods reporting on human capital: Utility analysis, Human resource accounting, Human resource costing and accounting, Value Addition, and the most important tool for HC measurement is the "Balanced Scorecard". The Balanced Scorecard approach gives little insight into intangibles' management. More specialized functional scorecards measuring intangibles were developed, ones of them called HR scorecards.

Table 2. The main approaches to reporting on Human Capital

\begin{tabular}{|l|l|l|l|l|}
\hline \multicolumn{1}{|c|}{ Approach } & \multicolumn{1}{|c|}{$\begin{array}{c}\text { Calculating } \\
\text { Coasts of } \\
\text { personnel } \\
\text { policies }\end{array}$} & \multicolumn{1}{|c|}{$\begin{array}{c}\text { Human Capital } \\
\text { accounting }\end{array}$} & $\begin{array}{c}\text { Human Capital } \\
\text { Management }\end{array}$ & \multicolumn{1}{c|}{$\begin{array}{c}\text { Strategic } \\
\text { Management }\end{array}$} \\
\hline Period of origin & Mid 1960s & Early 1960s & Late 1970s & Early 1990s \\
\hline Characteristics & $\begin{array}{l}\text { Financial utility } \\
\text { of personnel } \\
\text { selection }\end{array}$ & $\begin{array}{l}\text { Financial value of } \\
\text { enterprise's human } \\
\text { capital }\end{array}$ & $\begin{array}{l}\text { Learning and } \\
\text { dissemination of } \\
\text { knowledge as } \\
\text { internal } \\
\text { management } \\
\text { strategy }\end{array}$ & $\begin{array}{l}\text { The contribution of } \\
\text { financial indicators, } \\
\text { human capital, } \\
\text { internal business } \\
\text { processes, customer } \\
\text { relations and } \\
\text { innovation }\end{array}$ \\
\hline Method applied & Utility analysis & $\begin{array}{l}\text {-Human Resource } \\
\text { accounting } \\
\text {-Human resource } \\
\text { costing and } \\
\text { accounting }\end{array}$ & $\begin{array}{l}\text { - The learning } \\
\text { organization } \\
\text {-Knowledge } \\
\text { management }\end{array}$ & $\begin{array}{l}\text { The balanced } \\
\text { scorecard }\end{array}$ \\
\hline $\begin{array}{l}\text { Reporting } \\
\text { framework }\end{array}$ & $\begin{array}{l}\text { Cost and benefit } \\
\text { calculations }\end{array}$ & Financial statements & $\begin{array}{l}\text { Non-financial } \\
\text { statements (if any) }\end{array}$ & $\begin{array}{l}\text { Generic performance } \\
\text { measurements }\end{array}$ \\
\hline
\end{tabular}

Source: apdated from Westphalen, 1999, p.13

\subsection{The Balanced Scorecard}

The "balanced scorecard" is a performance measurement system developed by Kaplan and Norton in 1992, enhancing accounting information and building qualitative factors measures. 
In addition to the financial measures, performance is measured from three other perspectives: customers, internal business processes, and learning and growth. This would permit pursuing the financial results and tracking the development of its intangible assets, necessary for the organizations' growth.

Activity-Based Costing is the base for the BSC framework. It was defined by Kaplan and Bruns in 1987, Activity-Based Costing is an accounting methodology of resources costing assessment through activities used to develop products and services for customers, supporting strategic decisions like pricing and process and products/services improvement.

The balanced scorecard (BSC) is a translation of the firm's strategic goals into financial and non-financial objectives and performance measures (Kaplan and Norton 2001).

Many reasons motivate organizations to use the balanced scorecard (Rao, 2011, p.418-419):

- The balanced scorecard is a comprehensive tool to understand the target customers, their requirements, and the performance gaps.

- It provides logic for focusing on creating intangible and intellectual capital which under the traditional financial performance systems was difficult to do.

- In addition, the balanced scorecard is able to articulate the strategy of growth with business excellence which requires greater focus on non-financial initiatives, and enables employees to understand strategy and link strategic objectives to their day-to-day operations.

- Finally, it facilitates performance review and feedback on a continuous basis.

A successful implementation of the balanced scorecard has the following other prerequisites (Rao, 2011, p.419):

- Top management commitment and support,

- Determining the critical success factors,

- Translating these factors into measurable objectives (metrics),

- Linking performance measures to rewards, installing a simple tracking system,

- Creating and linking the balanced scorecards at all levels of the organization,

- Setting up a sound organizational communication system to harness advantages of the balanced scorecard,

- Linking strategic planning, balanced scorecard, and budgeting process for better allocation of resources (Pandey, 2005).

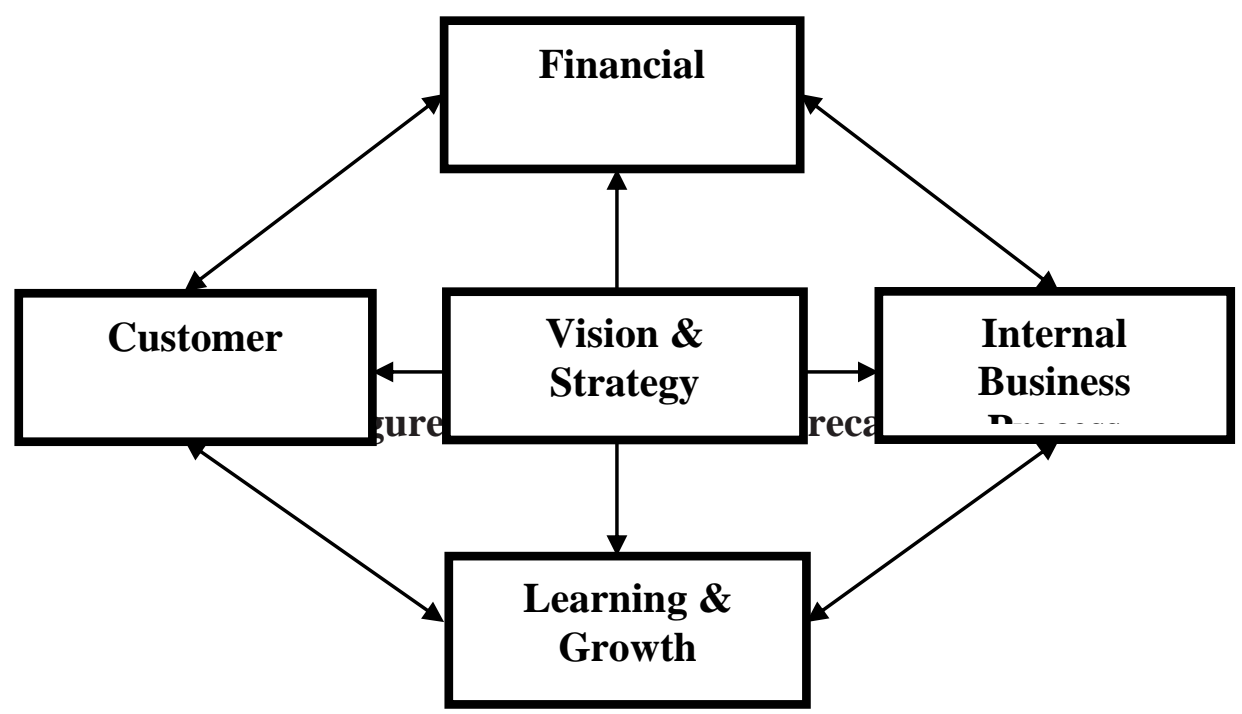

Source: apdated from Kaplan \& Norton, 1996, cited in Asan \& Tanyas, 2007, p.1001 
Kaplan \& Norton (2001) spread the utilization of scorecards to personal scorecards, making individuals major actors in the strategic management of the organization. "A strategy map (Kaplan \& Norton, 2001) provides clarity on the different items in an organization's Balanced Scorecard by linking them using a cause and effect chain, which connects desired outcomes with the drivers of those results" (Asan \& Tanyas, 2007, p. 1001).

Financial perspective is about the key drivers of financial performance, emphasizing cost efficiency (Charan et al., 2003). It answers the question: "how do we look to shareholders?". The customer perspective targets customer segments and position, with the objectif of finding ways to gain the organizations' high customer satisfaction (Charan et al., 2003). It answers the question "how do customers see us?"

The internal Business perspective is about to how work, processes, decisions, activities and actions are running. It answers the question "what we must excel at?"(Maureen, 2007)

Learning and growth perspective represents the intangible assets driving performance: human, information and organizational capital, as critical capabilities for the organizations' competitive advantage (Maureen, 2007; Charan et al., 2003). It answers the question "can we continue to improve and create value?',

Based on what is said, the researchers propose the following research model, by which he tries to explain the relationship between Human Capital Management and firm performance throughout the Balanced Scorecard.

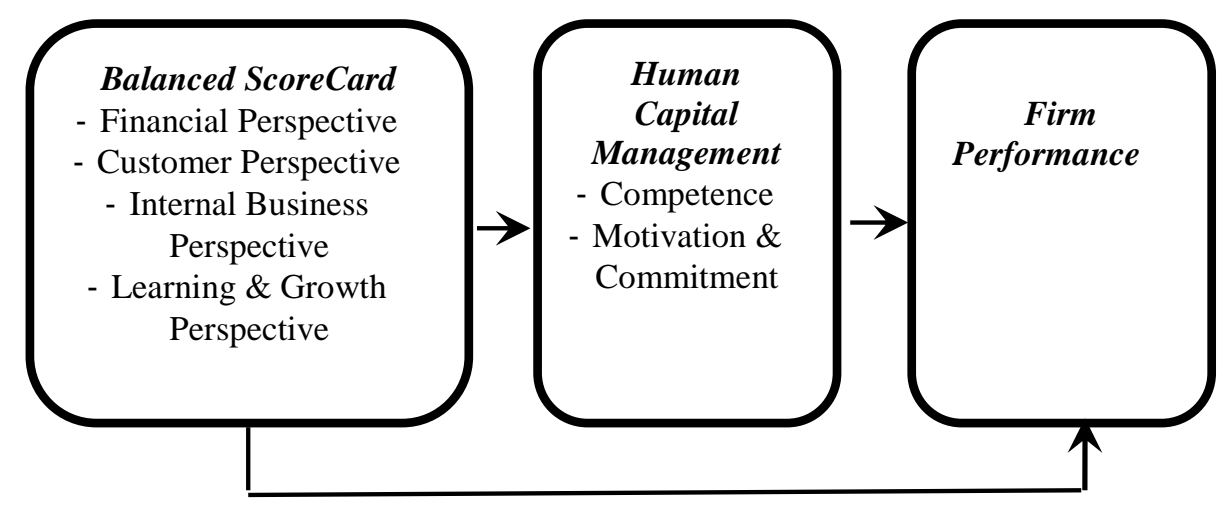

Figure 2. Effect of Human Capital Management on firm performance via Balanced scorecard

\section{HYPOTHESES DEVELOPMENT}

\subsection{Human Capital Management and Balanced Scorecard}

The BSC intends to reflect the necessity of balance between the traditional financial perspective and the three non-financial elements of customers, internal business processes and learning and growth.

The BSC provides means of pursuing short-term financial results and controlling the development of capabilities and intangible assets that engender growth and learning to improve internal business best processes, to provide value to targeted customers and thus reaching financial goals (Johanson et al., 1999). 
Based on that, researchers are looking for examining the impact of the existence of a BSC within an organization on the management of the human capital from the organizations' managers' perception; and that by hypothesizing as follow:

H.1. the Balanced Scorecard has a strong positive influence on managing effectively the organization's human capital.

\subsection{Human Capital Management and Firm Performance}

Research put interests on two main ways in which HCM could improve performance:

- via developing the employees' skills, through appropriate recruitment, training and development and retention effective programs.

- By reinforcing employees' motivation using for example attractive clear reward systems, participative problem solving and teamwork.

Competence, motivation and commitment indicate future capabilities, with long term investments, related and affecting most strongly the performance, where reporting them exhibits a balanced and informative account to stakeholders of their practices and performance in relation to these three indicators. (Task Force on Human Capital Management, 2003).

Therefore, the researchers try to test the following hypothesis:

H.2. Effective Human Capital Management has a strong positive influence on firms' performance.

\subsection{Balanced Scorecard and Firm Performance}

As a logical relationship, by examining the influence of BSC on HCM, and the effect of HCM on Firm performance; this would lead the researchers to examine the transitive relationship and effect of BSC on Firm performance.

As said before, the balanced scorecard propose looking at the organization's strategic shared vision from the four focus perspectives, allowing the monitoring of firm's performance.

Based on this, the researchers develop the following hypothesis:

H.3. The existence of a Balanced Scorecard would have a strong positive impact on firm performance.

\section{RESEARCH METHODOLOGY}

This cross sectional (one shot) study is a hypothesis testing, trying to explain the nature of relationship between Human Capital Management HCM and firm performance via Balanced Scorecard BSC. This study represents a field study conducted in telecommunication organizations including "orange, zain, umniah and express" which represent the unit of analysis.

\subsection{Measurement}

The measurement of items was taken from previous studies and merged items with the same meaning. The items for the HCM indicators: "competence" and "Motivation \& Commitment", in addition to firm performance items, were taken from (Hsu, 2006; Molina \& Ortega, 2002) and modified to fit the study.

Items measuring the BSC were also taken from related previous studies (Pandey, 2005; Manoj et al., 2005). Researcher has developed a balances scorecard reflecting different objectives that can be shared among telecommunication organizations. 
Each item was surveyed directly on a five point Likert type scale with scales named in the following manner: " 1 " strongly disagree, "2" disagree, "3" neutral, "4" agree, "5" strongly agree.

\subsection{Data collection}

Data used to test the research model were gathered from a non probability sample of respondents. The sample was selected on the basis of purposive sampling. Respondents were asked to select the appropriate response listed in the appendix.

Questionnaire was translated to Arabic language to become more understandable. A total of 40 questionnaires were distributed directly (personally), 34 were collected.

\section{DATA ANALYSIS AND RESULTS}

\subsection{Validity and Reliability}

The reliability for this study was measured by using Cronbach Alpha-coefficient in the statistical package for social science (SPSS) software. The value range from $86.4 \%$ (Motivation \& Commitment) to 75.5.4\% (Firm Performance). All variables in our research model demonstrated acceptable reliability. These coefficients are represented for each of the variables in Table 3:

Table 3. Reliability

\begin{tabular}{|l|l|c|c|c|}
\hline \multicolumn{1}{|c|}{ Variable } & \multicolumn{1}{|c|}{ Dimensions } & No. of Cases & No. of Items & Alpha \\
\hline \multirow{2}{*}{ Human Capital Management } & Motivation \& Commitment & 65 & 04 & 0.864 \\
\cline { 2 - 5 } & Competence & 65 & 05 & 0.779 \\
\hline \multirow{3}{*}{ Market Orientation } & Learning \& Growth & 65 & 08 & 0.815 \\
\cline { 2 - 5 } & Internal Business & 65 & 08 & 0.858 \\
\cline { 2 - 5 } & Customer & 65 & 07 & 0.839 \\
\cline { 2 - 5 } & Financial Performance & 65 & 06 & 0.798 \\
\hline \multirow{2}{*}{ Firm Performance } & 65 & 06 & 0.755 \\
\hline
\end{tabular}

Source: authors

\subsection{Hypotheses Testing}

The Analysis of Moment Structure examining the Linear Structural Relationship Model, was used to analyze the research model. The research examines the suggested model goodness of fit using six common model-fit indices. The comparison of model values indices with the recommended values in table (4) provides evidence of a good model fit. As a result, this goodness of fit makes possible the examination of the path coefficients of the structural model.

Table 4. Goodness of fit

\begin{tabular}{|l|c|c|}
\hline \multicolumn{1}{|c|}{ Fit Indices } & Model Value & Recommended Value \\
\hline CMIN/df & 2.1 & $<3.00$ \\
\hline Root mean square residual (RMR) & 0.00 & $\leq 0.05$ \\
\hline Goodness of fit (GFI) & 1.000 & $\geq 0.90$ \\
\hline Adjusted goodness of fit (AGFI) & 0.91 & $\geq 0.80$ \\
\hline Normed fit index (NFI) & 0.95 & $\geq 0.90$ \\
\hline Comparative fit index (CFI) & 0.98 & $\geq 0.90$ \\
\hline
\end{tabular}

Source: authors

To examine the estimated coefficients of the causal relationships between constructs, the researchers tested the hypotheses and determine the path coefficients based on suggested model using AMOS. Statistically, all of the path estimates are significant. Figure (3) demonstrates the coefficients of determination $\left(\mathrm{R}^{2}\right)$ of variables. 


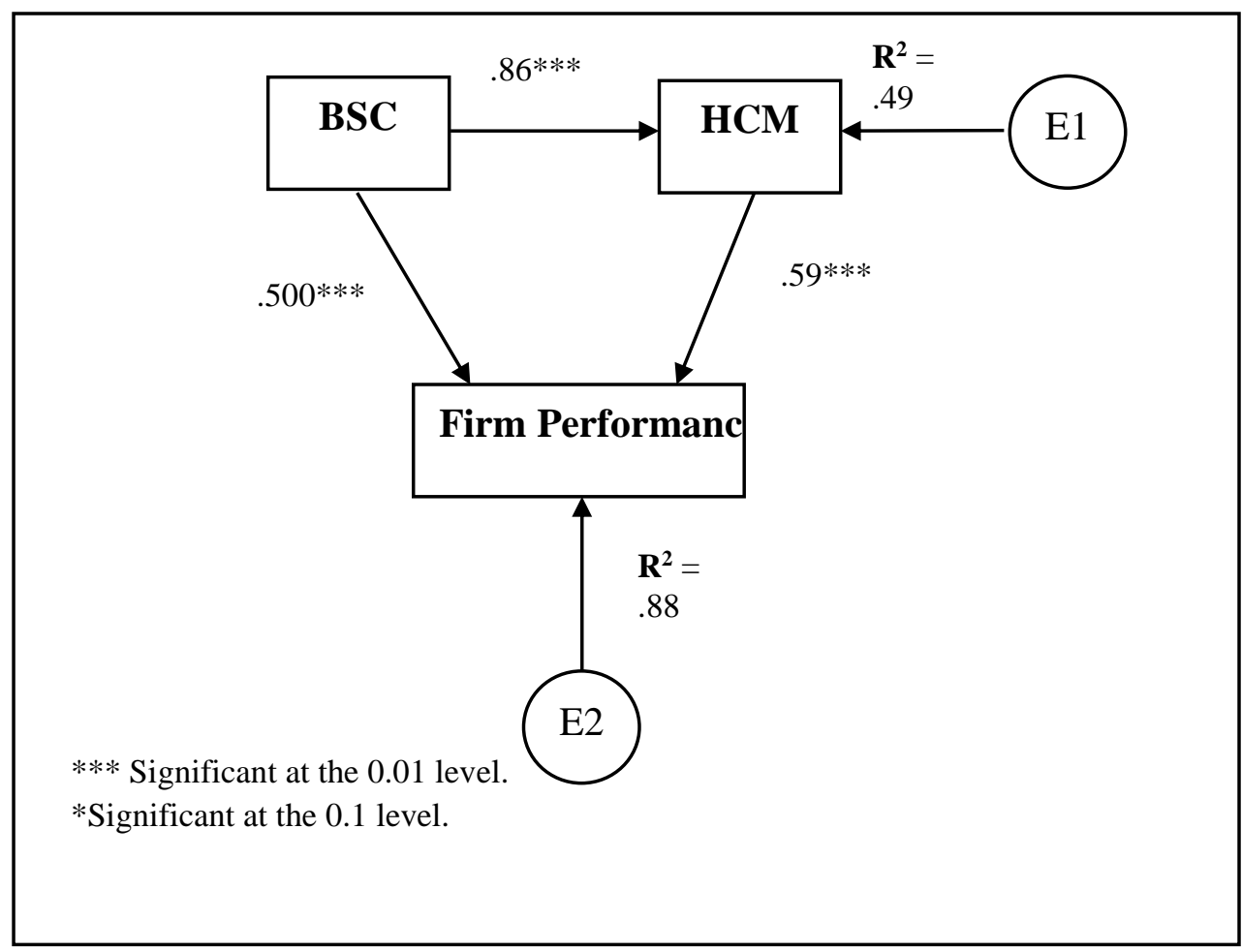

Source: authors

In addition to figure (2), table (3) illustrates the results of Structural Equation Modeling as follow:

Table 5. Results of structural equation modeling

\begin{tabular}{|l|c|c|c|c|}
\hline \multicolumn{1}{|c|}{ Path } & Estimate & S.E. & C.R. & P-value \\
\hline Balanced Scorecard $\longrightarrow$ HCM & .856 & .109 & 7.847 & .000 \\
\hline $\mathrm{HCM} \longrightarrow$ Firm Performance & .585 & .059 & 9.848 & .000 \\
\hline $\mathrm{BSC} \longrightarrow$ Firm Performance & .500 & .073 & 6.883 & .000 \\
\hline
\end{tabular}

S.E: Standard Error.

C.R: $\mathrm{t}$-value obtained by dividing the estimate of the covariance by the standard error.

Table (5) indicates significant positive effect of Balanced Scorecard on HCM $(\beta=0.48, t=$ 3.94, $\mathrm{p}=.000)$. Besides, HCM has a positive statistically significant impact on Firm Performance $(\beta=0.28, t=1.67, p=.093)$. So far, for deeper understanding of the nature of the impacts that each variable influences with one another, table (4) shows the direct and indirect effect between model's constructs.

The decomposition of the effects into direct and indirect one (Table (6)) indicates that Using Balanced Scorecard within the organization would directly and significantly impact the management of human capital $(\beta=.856)$. The use of BSC would explain $49 \%$ of the variance in HCM.

In the other hand, HCM has a direct positive effect $(\beta=.586)$ on the firm performance, and both HCM and BSC, this later that influence positively the firm performance $(\beta=.500)$, explain $88 \%$ of the variance in firm performance. What can be observed is the indirect effect of BSC of $(\beta=.44)$ on firm performance mediated by HCM. This result seems logical as BSC 
targets the efficiency and effectiveness of all the firm's activities, systems and processes, which would result in improving firm performance.

Generally, the three proposed hypotheses H.1, H.2, H.3 are accepted.

Table 6. Decomposition of effects

\begin{tabular}{|l|c|c|}
\hline \multicolumn{1}{|c|}{ Variable } & BSC & HCM \\
\hline HCM & & ---- \\
\hline Direct effect & 0.856 & --- \\
\hline Indirect effect & --- & --- \\
\hline Total effect & 0.856 & \\
\hline Firm Performance & & 0.586 \\
\hline Direct effect & 0.500 & ---- \\
\hline Indirect effect & 0.440 & 0.585 \\
\hline Total effect & 0.940 & \\
\hline
\end{tabular}

Numerous research were established by accountants researchers, studying relationship between human capital management and firm performance, taken human capital management from different perspectives and based on various human capital drivers and measures. Several indicators and drivers were proposed in literatures relating to human capital. In this study, researchers have taken into account the most important indicators in measuring human capital, and that based on different literatures and especially the many approaches suggesting them in the field of human capital and human capital accounting research. These indicators are: Competence, reflecting capitalizing skills and knowledge through recruiting excellence, training programs, retention ...The second indicator, Motivation and Commitment which makes employees using their skills and involvement in a consensus improvement of firm performance needed for its survival in the market.

Results show that HCM has a great impact on firm performance, so these findings suggest that in order to increase firm performance, investors and top managers have to make more investments in developing employees' skills, experiences and knowledge, and involve them to get increased learning capacity, talent development to yield the desired outcomes, precisely firm performance. This result supports the findings of Molina \& Ortega, 2002; Task force on Human Capital Managemnt; 2003.

On the other hand, the balanced scorecard is a strategic performance tool, one of the critical developments in management accounting, and supplement to the traditional financial measures, measuring intangible assets. A lot of studies have taken the study of using such tool on firm performance. This is why utilizing such a strategic tool would promote the effectiveness of the human capital management within organizations which in turn; either indirectly through the HCM which is considered as managing the most important asset and the source of sustainable competitive advantage; or directly, improve the firms' performance. These results support those of previous researches of Bassi \& McMurrer, 2007; Bassi et al., 2004; Westphalen, 1999; Johanson et al., 1999; Liao et al., 2006; Huselid \& Barnes, 2003; Butler, 2006; Pondey, 2005; Manoj et al., 2005; Kaplan \& Norton, 2007; Maureen, 2007.

\section{Conclusion}

Recently, intangible assets have been the main focus of accounting research as a source of firm performance. An increasing need to report on these intangibles is becoming one of the 
accounting preoccupations. This research has focus on human capital management as one non-financial asset. Researchers investigate the impact of the use of a Balanced Scorecard on the effectiveness of HCM. Moreover, researchers examine the impact of HCM and BSC on firm performance.

The findings of this search reveal that, first, consistent with previous studies, human capital management has significant impact on firm performance in Jordanian telecommunication organizations. Additionally, results support the resource-based and motivation theories in that competence and motivation and commitment are significant factors impacting on firm performance; While both the use of BSC method and HCM have a strong impact on promoting the telecommunication firms' performance.

This search also serves and support previous studies to inoculate organization from the pervasive myopia that results from the current system that continues to account for people only as costs. The researchers propose some recommendations based on the research findings. When human capital is an organizations' most important asset, it is imperative that it be measured and managed in a way that recognizes its centrality to the organizations success. In addition, top managers in telecommunication organizations have to recognize the utility and importance of balanced scorecard as a performance measure and the encouragement and the support its use can provide through translating corporate strategy

For future research, the researchers recommend for searching additional indicators measuring more accurately human capital in organizations, in addition it would be reasonable to expand the number of situations to which it applies. The researchers recommend testing results with a wider sample. Finally, it is recommended to test and use measures others than BSC, seeking for high standard by finding and deploying a set of human capital metrics that actually predict future business results.

\section{RERERENCES}

Asan, S. S., \& Tanyas, M. (2007). Integrating Hoshin Kanri and the Balanced Scorecard for Strategic Management: The Case of Higher Education. Total quality management and business excellence, 18(9), 999-1014. https://doi.org/10.1080/14783360701592604

Barney, J. (2002). Gaining and Sustaining Competitive Advantage. NJ: Prentice Hall

Bassi, L. Harrison, P. Ludwig, J., \& McMurrer, D. (2004). The impact of U.S firms investments in human capital on stock prices, unpublished.

Bassi, L., \& McMurrer, D. (2007). What to do when people are your most important asset. McBassi \& company.

Butler, M.G. (2006). Human resource outsourcing: the impact of managerial decisions on operating and market performance. University of Arkansas

Charan, K., Kumar, A., Saukhin, S., Amit, S., \& Moeller, M. (2003). Making Outsourcing Happen with Balanced Scorecard - a Unification Approach Paper (January 1, 2003). MIT E-commerce Research Forum. http://dx.doi.org/10.2139/ssrn.310139

Hartley, V., \& Robey, D. (2005). Reporting on human capital management. IES Report 423.

Haslinda, A. (2009). Evolving terms of human resource management and development. The Journal of International Social Research, 2(9), 180-186.

Huselid, A.M., \& Barnes, E.J. (2003). Human capital measurement systems as a source of competitive advantage. Rutgers University. 08854-8054.

Hsu, H-Y. (2006). Knowledge management and intellectual capital. Unpublished doctoral thesis. Southern Illinois University Carbondale. 
Johanson, U. Eklon, G. Holmgren, M., \& Martensson, M. (1999). Human resource costing and accounting versus the balanced scorecard: a literature survey of experience with the concepts. School of business. Stockholm University.

Kaplan, R. S., \& Norton, D. P. (2007). Using balanced scorecard as a strategic management system. Harvard business review.

Kaplan, R. S., \& Norton, D. P. (2001). The strategy-focused organization. Strategy \& Leadership, May/June.

Kucharpíková, A., Tokarpíková, E., \& Blašková, M. (2015). Human Capital Management Aspect of The Human Capital Efficiency in University Education. Procedia - Social and Behavioral Sciences, 177, 48 - 60. https://doi.org/10.1016/j.sbspro.2015.02.332

Liao, C-H., Mo, S., \& Grant.J. (2006). Market implication of human capital investment. Case Western Reserve University. Cleveland, OH 44106.

Manoj, A. Sahay, B. S. \& Saha, S. (2005). Balanced Scorecard in indian companies. VIKALPA, 30(02). DOI: 10.1177/0256090920050202

Maureen, A. (2007). A balanced Scorecard for the clinical laboratory. California state university. Dominguez hills.

Molina, J. A. \& Ortega, R. (2002). Can effective human capital management lead to measured firm performance?. University of Zaragoza. Zaragoza, Spain.

Nyce, S. A., \& Schieber, S. J. (2006). The Economic Implications of Aging Societies: The Costs of Living Happily Ever After. Cambridge University Press, New York, USA.

Oliver, C. (1997). Sustainable competitive advantage: Combining institutional and resourcebased views. Strategic management journal, 18(9), 697-713. https://doi.org/ 10.1002/(SICI)1097-0266(199710)18:9<697::AID-SMJ909>3.0.CO;2-C

Pandey, I. M. (2005). Balanced Scorecard: myth and reality. VIKALPA, 30(1). https://doi.org/10.1177/0256090920050105

Rao, P. M. (2011). Financial statement analysis and reporting. PHI Learning Private Limited, New Delhi, India.

Teece, D., Pisano, G. and Schuen, A. (1997). Dynamic capabilities and strategic management. Strategic Management Journal, 18 (7), 509-533. https://doi.org/10.1002/(SICI)10970266(199708)18:7<509::AID-SMJ882>3.0.CO; 2-Z

Westphalen, S-A. (1999). Reporting on Human Capital; Objectives and Trends. International Symposium. Amesterdam of Measuring and reporting intellectual capital experience. Issues and prospects: reporting on human capital, objectives and trends. 